MaPan : Jurnal Matematika dan Pembelajaran

p-ISSN: 2354-6883 ; e-ISSN: 2581-172X

Volume 5, Nomor 1, Juni 2017

\title{
APLIKASI STRATEGI KOGNITIF UNTUK MENINGKATKAN KEMAMPUAN SISWA DALAM MEMAHAMI MATERI PEMBELAJARAN LOGARITMA DI KELAS $X$ MATEMATIKA DAN ILMU ALAM (MIA) 5 SMA NEGERI 2 PALOPO
}

\author{
Andi Ika Prasasti Abrar1), Mitha Utami Amalia2) \\ 1,2Fakultas Tarbiyah dan Keguruan UIN Alauddin Makassar \\ 1,2Kampus II: Jalan H. M. Yasin Limpo Nomor 36 Samata-Gowa \\ E-mail: asty_math03@yahoo.co.id ${ }^{1}$, mithautamiamalia@yahoo.com $^{2}$
}

\begin{abstract}
Abstrak:
Penelitian ini bertujuan untuk mengetahui aktivitas siswa dalam aplikasi strategi kognitif pada materi logaritma, mengetahui respon siswa terhadap aplikasi strategi kognitif, dan mengetahui strategi kognitif dalam meningkatkan kemampuan siswa memahami materi pembelajaran logaritma pada kelas X MIA 5 SMA Negeri 2 Palopo. Penelitian ini dilakukan sebanyak dua siklus. Setiap siklus berlangsung selama 4 kali pertemuan. Subjek penelitian adalah siswa kelas X MIA 5 dengan jumlah 31 orang siswa. Instrumen yang digunakan berupa tes, lembar observasi siswa maupun guru dan angket respon siswa. Data dari hasil tes dan hasil angket respon siswa dianalisis secara kuantitatif, sedangkan data dari hasil lembar observasi dianalisis secara kualitatif. Hasil penelitian menunjukkan bahwa rata-rata hasil belajar matematika kompetensi pengetahuan siswa pada siklus I adalah 2,6142 dari skor ideal 4 dengan predikat B- sedangkan skor rata-rata hasil belajar pada siklus II adalah 3,0697 dari skor ideal 4 dengan predikat B ${ }^{+}$. Skor ratarata hasil belajar kompetensi sikap spiritual pada siklus I adalah 2,91 dengan predikat Baik (B) sedangkan pada siklus II meningkat menjadi 3,42 dengan predikat Sangat Baik (SB). Skor rata-rata hasil belajar kompetensi sikap sosial pada siklus I adalah 2,77 dengan predikat Baik (B) sedangkan pada siklus II meningkat menjadi 3,09 dengan predikat Baik (B). Sementara itu rata-rata aktivitas siswa pada siklus I adalah 43 dan pada siklus II meningkat menjadi 46. Selain itu, hasil observasi aktivitas guru dan respon siswa terhadap pengaplikasian strategi kognitif dalam belajar matematika juga mengalami peningkatan. Dengan demikian, dapat disimpulkan bahwa kemampuan siswa dalam memahami materi pembelajaran logaritma di kelas $X$ Matematika dan Ilmu Alam (MIA) 5 SMA Negeri 2 Palopo mengalami peningkatan melalui pengaplikasian strategi kognitif dalam belajar matematika.
\end{abstract}

Kata Kunci: Strategi Kognitif, Pembelajaran Logaritma 
$\mathrm{P}$ endidikan merupakan bagian yang sangat penting dalam mewujudkan pembangunan nasional, karena pendidikan adalah aktifitas dan usaha manusia untuk meningkatkan kepribadiannya dengan jalan membina potensi-potensi pribadinya, yaitu rohani dan jasmani. Meskipun demikian, banyak negara mengakui bahwa persoalan pendidikan merupakan persoalan yang kompleks, tetapi hampir sebagian dari negara tersebut mengalami usaha dan kerja keras untuk memajukan pendidikan, karena dengan pendidikan derajat seorang manusia akan diangkat ke tingkat yang lebih tinggi.

Firman Allah swt. dalam QS. al-Mujadilah / 58: 11

Terjemahnya:

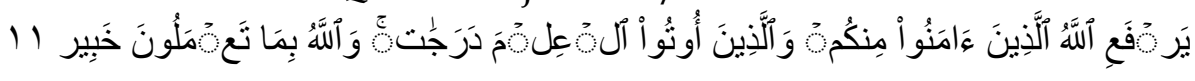

Allah akan meninggikan orang-orang beriman diantaramu dan orang-orang yang diberi ilmu pengetahuan beberapa derajat. Dan Allah Maha Mengetahui apa yang kamu lakukan (Departemen Agama, 2010).

Dalam rangka meningkatkan taraf pendidikan yang kemudian dapat menumbuhkan manusia-manusia yang berkualitas bukan hanya tanggung jawab beberapa pihak saja melainkan tanggung jawab semua elemen bangsa, sebab pendidikan merupakan suatu hal yang pokok dalam kehidupan manusia. Oleh karena itu, pendidikan harus dapat dirasakan oleh semua pihak dalam bangsa ini baik yang kaya maupun yang miskin. Ini sesuai dengan tujuan pendidikan nasional yang tercantum dalam pembukaan Undang-Undang Dasar 1945, yaitu mencerdaskan kehidupan bangsa.

Untuk menunjang terwujudnya tujuan pendidikan nasional tersebut perlu dilakukan upaya peningkatan kualitas pendidikan di setiap jenjang pendidikan. Salah satu upaya yang dapat dilakukan adalah meningkatkan kualitas pendidikan matematika.

Matematika merupakan salah satu bidang studi yang mampu membentuk pola pikir manusia sehingga dapat membuatnya berfikir secara logis dan realistis dalam pengembangan ilmu pengetahuan dan teknologi dalam rangka peningkatan kualitas pendidikan.

Melihat pentingnya peranan matematika dalam menciptakan sumber daya manusia yang berkualitas, berbagai hal dilakukan dalam rangka meningkatkan kualitas belajar matematika siswa di antaranya, penyempurnaan kurikulum, pengembangan silabus maupun bahan ajar, penataran guru-guru matematika, penambahan sarana dan prasarana, dan 
berbagai usaha lainnya yang telah dilakukan baik oleh pemerintah maupun oleh instansi-instansi lain yang peduli dalam dunia pendidikan.

Namun pada kenyataannya, dalam pelaksanaan pendidikan menunjukkan bahwa kualitas belajar matematika siswa belum optimal. Hasil riset yang dilakukan oleh Organization for Economic Co-Operation and Development (OECD) dengan menggunakan metode Programme for International Student Assesment (PISA) membuktikan bahwa dari pelajar di 65 negara/kota yang disurvei, pelajar Indonesia berada di peringkat ke dua terbawah dalam pelajaran matematika, bahkan mayoritas pelajar di Indonesia belum mencapai level 2 (level 1 adalah level terendah sedangkan level 6 adalah level tertinggi) untuk matematika $(75,7 \%)$.

Dari kenyataan tersebut dapat diduga penyebab mengapa kualitas belajar matematika siswa belum optimal antara lain persepsi siswa yang menganggap matematika adalah momok yang menakutkan, minat siswa terhadap matematika rendah, proses belajar mengajar yang masih didominasi oleh metode konvensional, siswa kurang berani bertanya pada saat proses belajar mengajar, siswa kurang termotivasi menyelesaikan tugas-tugas di rumah dan siswa kurang memahami setiap materi / konsep pelajaran matematika.

Diantara sejumlah permasalahan yang dikemukakan di atas sebenarnya ada satu masalah utama yang perlu mendapat perhatian, yaitu yang berkaitan dengan pemahaman siswa terhadap materi pelajaran matematika. Sebagian besar siswa kurang paham dalam belajar matematika dikarenakan guru selalu terfokus bagaimana mengajar tetapi kurang memperhatikan bagaimana siswa mau belajar.

Berdasarkan informasi yang diperoleh dari guru matematika di SMA Negeri 2 Palopo khususnya guru matematika wajib kelas X Matematika dan Ilmu Alam (MIA) 5 bahwa kemampuan siswa dalam memahami materi pelajaran matematika masih tergolong rendah. Hal ini terbukti, jika siswa diberi pertanyaan tentang materi pelajaran yang sedang dipelajari, siswa tersebut belum bisa menjawab pertanyaan padahal substansi pertanyaan sama dengan contoh yang diberikan. Selain itu, siswa juga belum bisa belajar secara mandiri dikarenakan mereka belum memiliki pengetahuan tentang bagaimana seharusnya belajar itu (Suhermiati, 2014).

Rendahnya kemampuan siswa dalam memahami materi pelajaran matematika juga diperkuat dengan adanya rata-rata hasil belajar matematika 
siswa sebelum pelaksanaan tindakan yaitu sebesar 1,6129 dengan persentase ketuntasan klasikal sebesar 6,46\%.

Kondisi ini terjadi antara lain karena guru hanya terfokus pada bagaimana cara menerapkan berbagai model dan metode pembelajaran yang disesuaikan dengan kurikulum yang berlaku agar siswa mampu memahami materi pelajaran matematika dengan baik tetapi, tidak mengajari siswa bagaimana cara untuk belajar.

Upaya yang diperkirakan dapat meningkatkan kemampuan siswa dalam memahami materi pelajaran matematika adalah dengan mengaplikasikan salah satu strategi belajar yaitu strategi kognitif. Strategi kognitif merupakan strategi yang lebih mengacu pada pemikiran tentang halhal yang perlu dilakukan untuk memahami sesuatu yang dipelajari. Berdasarkan teori kognitif dan pemrosesan informasi, ada tiga varians strategi kognitif, yaitu strategi mengulang (rehearsal strategies), strategi elaborasi (elaboration strategies), dan strategi organisasi (organization strategies). Melalui pengaplikasian strategi kognitif, selain kemampuan siswa dalam memahami materi pelajaran matematika dapat meningkat, siswa juga diharapkan menjadi pembelajar dengan pengendalian diri / mandiri (Trianto, 2013: 86).

Atas dasar inilah penulis mencoba untuk mengaplikasikan strategi kognitif dalam proses pembelajaran. Diharapkan melalui strategi tersebut siswa mampu mengembangkan kemampuannya secara optimal dalam memahami pelajaran matematika.

\section{STRATEGI KOGNITIF}

Strategi merupakan pendekatan umum mengajar yang berlaku dalam berbagai bidang materi. Pendekatan umum dalam mengajar tersebut digunakan untuk memenuhi berbagai tujuan pembelajaran (Paul, 2012: 6). Sulistyono dalam Trianto berpendapat bahwa strategi belajar merupakan sebuah tindakan khusus yang dilakukan oleh seseorang yang dapat membantunya dalam memahami sesuatu.

Menurut Rigney dalam Soma Salims, strategi kognitif adalah operasioperasi yang dilakukan atau prosedur mental yang bisa digunakan oleh seorang individu agar bisa mendapatkan, menahan, serta memperoleh kembali berbagai pengetahuan dan kepandaian.

Strategi-strategi tersebut merupakan strategi-strategi yang digunakan siswa untuk memecahkan masalah belajar tertentu dalam situasi dan kondisi tertentu pula agar memperoleh pengetahuan dan kepandaian. 
Strategi belajar sangat penting dan mutlak untuk diajarkan kepada siswa karena keberhasilan siswa bergantung pada kemahiran untuk belajar secara mandiri dan memonitor belajar mereka sendiri.

Salah satu strategi belajar adalah strategi kognitif. Disebut strategi kognitif karena menitikberatkan pada kognisi seseorang. Secara etimologis, istilah cognitive-strategy diturunkan dari kata kerja Latin co-agitare dan kata strategema, atis. Kata co-agitare memiliki arti, yaitu memikirkan, merencanakan, merancang, dan mereka-reka. Sedangkan kata strategema, atis berarti siasat. Dengan demikian, strategi kognitif dapat diartikan sebagai siasat untuk mengerti.

Tujuan utama dari pengajaran strategi adalah mengajarkan siswa untuk belajar atas kemauan dan kemampuan diri sendiri atau pembelajar mandiri (self-regulated learner). Karena menurut Weinstein dan Meyer dalam Jamil Suprihatiningrum, pengajaran yang baik dan sukses meliputi mengajarkan siswa bagaimana belajar, mengajarkan siswa bagaimana mengingat, mengajarkan siswa bagaimana berfikir, dan mengajarkan siswa bagaimana memotivasi diri sendiri (Jamil, 2013: 48)

Oleh karena itu, mengembangkan dan mengajarkan strategi-strategi belajar kepada siswa merupakan tugas seorang guru untuk membentuk siswa menjadi pembelajar dengan pengendalian diri.

\section{VARIANS TRATEGI BELAJAR KOGNITIF}

Berdasarkan teori kognitif dan pemrosesan informasi, maka terdapat beberapa strategi belajar yang dapat digunakan dan diajarkan, yaitu:

a. Strategi Mengulang (Rehearsal Strategies)

Agar terjadi pembelajaran, pebelajar harus melakukan tindakan pada informasi baru dan menghubungkan informasi baru tersebut dengan pengetahuan awal. Strategi yang digunakan untuk proses pengkodean ini disebut strategi mengulang (rehearsal strategies). Strategi mengulang terdiri dari strategi mengulang sederhana (rote rehearsal) dengan cara mengulangulang dan strategi mengulang kompleks dengan cara menggaris bawahi ideide utama (under lining) dan membuat catatan pinggir (marginal note).

Strategi mengulang yang paling sederhana, yaitu sekedar mengulang dengan keras atau dengan pelan informasi yang ingin kita hafal disebut strategi mengulang sederhana (rote rehearsal). Namun, seorang pembelajar tidak dapat mengingat seluruh kata atau ide dalam sebuah buku hanya dengan membaca buku itu keras-keras. Untuk itu, diperlukan yang namanya 
strategi mengulang kompleks dengan cara menggaris bawahi dan membuat catatan pinggir.

1) Menggaris Bawahi

Menggaris bawahi membantu siswa belajar lebih banyak dari teks karena beberapa alasan. Pertama, menggaris bawahi secara fisik menemukan ide-ide kunci, oleh karena itu, pengulangan dan penghafalan lebih cepat dan lebih efisien. Kedua, proses pemilihan apa yang digaris bawahi membantu dalam menghubungkan informasi baru dengan pengetahuan yang telah ada (Trianto, 2011: 146)

2) Membuat Catatan Pinggir

Membuat catatan pinggir dan catatan lain membantu dalam melengkapi pemberian garis bawah yang sudah dilakukan.

b. Strategi Elaborasi (Elaboration Strategies)

Elaborasi merupakan proses penambahan rincian sehingga informasi baru akan menjadi lebih bermakna. Strategi elaborasi membantu pemindahan informasi baru dari memori jangka pendek ke memori jangka panjang dengan menciptakan gabungan dan hubungan antara informasi baru dengan apa yang telah diketahui.

1) Pembuatan Catatan (Note Taking)

Sejumlah besar informasi diberikan kepada siswa melalui presentasi dan demonstrasi guru. Pembuatan catatan membantu siswa dalam mempelajari informasi ini secara singkat dan padat menyimpan informasi untuk ulangan dan dihafal kelak.

2) Analogi

Menurut Kamus Besar Bahasa Indonesia, analogi berarti persamaan atau persesuaian antara dua hal yang berbeda (Meity, 2011: 20). Dalam bahasa Arab, analogi diartikan sebagai qasa yang berarti mengukur atau membandingkan. Jadi, dapat disimpulkan bahwa analogi merupakan pembandingan yang dibuat untuk menunjukan kesamaan antara ciri-ciri pokok suatu benda atau ide-ide.

3) Metode $P Q 4 R$

Metode $P Q 4 R$ digunakan untuk membantu siswa mengingat apa yang mereka baca. P singkatan dari preview (membaca selintas dengan cepat), Q adalah question (bertanya), dan $4 \mathrm{R}$ singkatan dari read (membaca), reflect (refleksi), recite (tanya-jawab sendiri), review (mengulang secara menyeluruh). Melakukan preview dan mengajukan pertanyaan-pertanyaan sebelum 
membaca mengaktifkan pengetahuan awal dan mengawali proses pembuatan hubungan antara informasi baru dengan apa yang telah diketahui.

c. Strategi Organisasi (Organization Strategies)

Seperti halnya strategi elaborasi, strategi organisasi bertujuan membantu pebelajar meningkatkan kebermaknaan bahan-bahan baru, terutama dilakukan dengan mengenakan struktur-struktur pengorganisasian baru pada bahan-bahan tersebut. Outlining, mapping, dan mnemonics yang meliputi pemotongan, akronim, dan kata terkait merupakan strategi organisasi yang umum.

1) Outlining

Dalam outlining atau membuat kerangka garis besar, siswa belajar menghubungkan berbagai macam topik atau ide dengan beberapa ide utama. Sama dengan strategi lain, siswa jarang sebagai pembuat kerangka yang baik pada awalnya, namun mereka dapat belajar menjadi penulis kerangka yang baik apabila diberikan pengajaran tepat dan latihan yang cukup.

2) Pemetaan Konsep (Mapping Concept)

"Concept map (peta konsep) adalah representase visual untuk hubungan diantara ide-ide".

Menurut Martin, pemetaan konsep merupakan sebuah terobosan baru yang penting yang dapat membantu anak menghasilkan pembelajaran bermakna yang terjadi di dalam kelas (Trianto, 2011: 157)

Peta konsep menyediakan bantuan visual konkret untuk membantu mengorganisasikan informasi sebelum informasi tersebut dipelajari.

3) Mnemonics

Mnemonics merupakan strategi untuk membantu menata informasi yang menjangkau ingatan dalam pola-pola yang dikenal, sehingga lebih mudah dicocokkan dengan pola skemata dalam memori jangka panjang. Contoh dari mnemonics, yaitu chunking (potongan), akronim (singkatan), dan link-work (kata berkait).

\section{MATERI PEMBELAJARAN LOGARITMA}

Materi pembelajaran yang diajarkan dalam penelitian ini disesuaikan dengan kurikulum berjalan di kelas X SMA Negeri 2 Palopo. Berdasarkan kurikulum semester ganjil tahun pembelajaran 2014/ 2015, materi pembelajaran di kelas X SMA menyangkut topik Logaritma. Logaritma merupakan salah satu materi yang telah diajarkan di kelas IX Sekolah Menengah Pertama. Topik tersebut dapat diajarkan melalui pengaplikasian 
strategi kognitif agar siswa lebih mudah memahami materi pelajaran yang berkaitan dengan topik tersebut.

Selanjutnya, siswa dikatakan memahami materi apabila siswa mampu menyelesaikan soal-soal yang telah dirancang khusus sebelumnya oleh peneliti agar memuat indikator pemahaman. Indikator pemahaman yang dimaksud adalah sebagai berikut:

a. Siswa mampu menyatakan ulang sebuah kosep yang diberikan

b. Siswa mampu mengklasifikasikan obyek-obyek tertentu menurut sifat-sifat tertentu (sesuai dengan konsepnya)

c. Siswa mampu memberi contoh dan bukan contoh dari konsep

d. Siswa mampu menyajikan konsep dalam berbagai bentuk representasi matematis

e. Siswa mampu mengembangkan syarat perlu dan syarat cukup suatu konsep

f. Siswa mampu menggunakan, memanfaatkan, dan memilih prosedur atau operasi tertentu

g. Siswa mampu mengaplikasikan atau algoritma dalam memecahkan masalah.

\section{METODE PENELITIAN}

Jenis penelitian yang digunakan adalah penelitian tindakan kelas (Classroom Action Research) yang berlangsung selama dua siklus. Setiap siklus terdiri dari empat tahap, yaitu tahap perencanaan (Planning), tahap Observasi (Observating) dan tahap Refleksi (Reflection). Penelitian ini dilakukan di kelas X Matematika dan Ilmu Alam (MIA) 5 SMA Negeri 2 Palopo. Jl. Garuda Perumnas, Kelurahan Rampoang, Kecamatan Bara, Kota Palopo.

Sumber data pada penelitian ini adalah Siswa kelas $X$ Matematika dan Ilmu Alam (MIA) 5 SMA Negeri 2 Palopo yang berjumlah 31 orang, yaitu 10 orang siswa laki-laki dan 21 orang siswa perempuan merupakan data primer. Sumber data tertulis berupa sumber dari perangkat pembelajaran guru, arsiparsip guru matematika dan arsip tata usaha SMA Negeri 2 Palopo merupakan data sekunder.

Jenis data yang digunakan pada penelitian ini, yaitu data kualitatif berupa lembar/format observasi dan data kuantitatif berupa angket respon siswa dan hasil tes/belajar, yakni skor kemampuan siswa dalam menyelesaikan soal. 
Teknik pengumpulan data yang digunakan dalam penelitian ini adalah Teknik Angket dan Teknik Observasi

\section{HASIL PENELITIAN DAN PEMBAHASAN}

\section{Data Awal Siswa}

Sebelum melaksanakan penelitian dengan mengaplikasikan strategi kognitif dalam belajar matematika siswa maka terlebih dahulu peneliti mengambil nilai hasil belajar siswa dengan memberikan tes untuk mengetahui kemampuan siswa dalam memahami materi pelajaran matematika sebagai perbandingan hasil belajar prasiklus, siklus I, dan siklus II.

Tabel 1. Distribusi Frekuensi dan Persentase Skor Hasil Belajar Matematika Siswa pada Tes Awal

\begin{tabular}{|c|c|c|c|c|}
\hline No. & $\begin{array}{l}\text { Rentang } \\
\text { Nilai }\end{array}$ & Predikat & Frekuensi & Persentase \\
\hline 1. & $\begin{array}{c}0<\text { Skor } \leq \\
1,00\end{array}$ & $\mathrm{D}$ & 3 & $9,68 \%$ \\
\hline 2. & $\begin{array}{c}1,00<\text { Skor } \\
\leq 1,33\end{array}$ & $\mathrm{D}^{+}$ & 8 & $25,81 \%$ \\
\hline 3. & $\begin{array}{c}1,33<\text { Skor } \\
\leq 1,66\end{array}$ & $\mathrm{C}^{-}$ & 10 & $32,26 \%$ \\
\hline 4. & $\begin{array}{c}1,66<\text { Skor } \\
\leq 2,00\end{array}$ & $\mathrm{C}$ & 2 & $6,45 \%$ \\
\hline 5. & $\begin{array}{c}2,00<\text { Skor } \\
\leq 2,33\end{array}$ & $\mathrm{C}^{+}$ & 4 & $12,90 \%$ \\
\hline 6. & $\begin{array}{c}2,33<\text { Skor } \\
\leq 2,66\end{array}$ & $\mathrm{~B}^{-}$ & 2 & $6,45 \%$ \\
\hline 7. & $\begin{array}{c}2,66<\text { Skor } \\
\leq 3,00\end{array}$ & B & 2 & $6,45 \%$ \\
\hline 8. & $\begin{array}{c}3,00<\text { Skor } \\
\leq 3,33\end{array}$ & $\mathrm{~B}^{+}$ & - & - \\
\hline 9. & $\begin{array}{c}3,33<\text { Skor } \\
\leq 3,66\end{array}$ & $\mathrm{~A}^{-}$ & - & - \\
\hline 10. & $\begin{array}{c}3,66<\text { Skor } \\
\leq 4,00\end{array}$ & A & - & - \\
\hline & Jumlah & & 31 & $100 \%$ \\
\hline
\end{tabular}


Selanjutnya, skor hasil nilai awal siswa dikelompokkan ke dalam kategori tuntas dan tidak tuntas hasil belajarnya maka diperoleh tabel distribusi frekuensi dan persentase sebagai berikut:

Tabel 2. Distribusi Frekuensi Ketuntasan Hasil Belajar Matematika Siswa Pada Tes Awal

\begin{tabular}{lccc}
\hline \multicolumn{1}{c}{ Skor } & Kategori & Frekuensi & Persentase \\
\hline $0<$ Skor $\leq 2,66$ & $\begin{array}{c}\text { Tidak } \\
\text { Tuntas }\end{array}$ & 29 & $93,55 \%$ \\
$2,66<$ Skor $\leq 4,00$ & Tuntas & 2 & $6,45 \%$ \\
\hline Jumlah & & 31 & $100 \%$ \\
\hline
\end{tabular}

Tabel 2 menunjukkan bahwa kemampuan siswa dalam memahami pelajaran matematika masih kurang. Oleh karena itu, perlu diadakan perbaikan dengan mengaplikasikan strategi kognitif dalam belajar matematika.

\section{Siklus I}

a. Tahap Perencanaan (Planning)

Persiapan yang dilakukan sebelum pelaksanaan tindakan pada siklus I adalah melakukan telaah silabus sesuai dengan Kurikulum 2013 SMA materi logaritma. Dari hasil telaah ini ditetapkan kompetensi dasar yang akan diajarkan pada siklus I. Jadwal kegiatan pelaksanaan siklus I ditetapkan 4 kali pertemuan. Masing-masing pertemuan berlangsung selama $2 \times 45$ menit. Pertemuan pertama tanggal 16 Agustus 2014 membahas tentang konsep logaritma, pertemuan kedua tanggal 21 Agustus 2014 membahas tentang sifatsifat logaritma, pertemuan ketiga tanggal 23 Agustus 2014 masih membahas tentang sifat-sifat logaritma, dan pertemuan keempat tanggal 28 Agustus 2014 adalah pemberian tes hasil belajar siklus I.

Selain itu, peneliti juga membuat sejumlah perangkat pembelajaran yang dibutuhkan dalam proses pembelajaran seperti RPP (Rencana Pelaksanaan Pembelajaran) dan Lembar Kerja Siswa (LKS), merancang segala instrumen yang dibutuhkan dalam proses penelitian seperti lembar observasi, angket respon siswa, dan kisi-kisi soal serta soal sebagai alat evaluasi. 
b. Tahap Pelaksanaan Tindakan (Acting)

Pada tahap ini, peneliti mengajar sesuai dengan Rencana Pelaksanaan Pembelajaran (RPP) yang telah dibuat. Pada tahap ini pula siswa melakukan aktivitas belajar dengan mengaplikasikan strategi kognitif.

c. Tahap Observasi (Observating)

1) Hasil observasi siklus I

Pada tahap ini, dilakukan observasi pada saat proses belajar mengajar sedang berlangsung berupa pengamatan terhadap aktivitas peneliti yang bertindak sebagai guru dan pengamatan terhadap aktivitas siswa sesuai dengan indikator-indikator dalam strategi kognitif yang digunakan dalam kegiatan pembelajaran.

Kegiatan observasi tersebut melibatkan empat orang observer untuk mempermudah pengamatan dan agar penilaian lebih objektif. Satu orang observer mengamati aktivitas peneliti, dan tiga orang observer lainnya mengamati aktivitas siswa. Sementara itu, peneliti mengamati hasil belajar kompetensi sikap spiritual dan kompetensi sikap sosial siswa.

Hasil observasi aktivitas siswa pada siklus I dirangkum secara singkat dalam tabel berikut:

Tabel 3. Hasil Observasi Aktivitas Siswa Pada Siklus I

\begin{tabular}{clc}
\hline No. & $\begin{array}{c}\text { Indikator Observasi } \\
\text { Aktivitas Siswa }\end{array}$ & $\begin{array}{c}\text { Perolehan (Rerata) } \\
\text { Kelas }\end{array}$ \\
\hline 1. & Strategi Mengulang & 76 \\
2. & Strategi Elaborasi & 36 \\
3. & Strategi Organisasi & 17 \\
Jumlah & & 129 \\
Rata-Rata & & 43 \\
\hline
\end{tabular}

Berdasarkan tabel di atas terlihat bahwa rata-rata aktivitas siswa pada siklus I adalah 43. Sementara itu, hasil observasi aktivitas guru pada siklus I, diantaranya dapat dilihat dari jumlah frekuensi guru mengarahkan dan/atau membimbing siswa untuk mengaplikasikan strategi kognitif. Oleh karena itu, penelitian dilanjutkan ke siklus II.

2) Analisis Penilaian Sikap Spiritual dan Sosial Siklus I

Penilaian terhadap sikap spiritual pada siklus I dilakukan melalui observasi dengan memperhatikan tiga indikator yaitu berdoa sebelum dan sesudah melakukan kegiatan pembelajaran, mengucapkan salam sebelum dan 
sesudah kegiatan pembelajaran, dan mengungkapkan kekaguman secara lisan atas kebesaran Tuhan. Ketiga indikator ini merupakan indikator untuk melihat seberapa besar hasil belajar siswa pada kompetensi sikap spiritual. Penilaian terhadap sikap spiritual siswa dilakukan dalam setiap pertemuan melalui observasi oleh peneliti secara langsung.

Secara singkat hasil penilaian sikap spiritual yang diperoleh siswa dideskripsikan sebagai berikut.

Tabel 4. Perolehan Penilaian Sikap Spiritual Pada Siklus I

\begin{tabular}{|c|c|c|c|c|}
\hline \multirow[b]{2}{*}{ No. } & \multirow[b]{2}{*}{ Indikator } & \multirow{2}{*}{$\begin{array}{c}\text { Perolehan } \\
\text { Ketercapaian } \\
\text { (Rerata Kelas) } \\
\text { dalam \% }\end{array}$} & \multicolumn{2}{|c|}{ Penilaian } \\
\hline & & & $\begin{array}{c}\text { Konversi } \\
\text { Nilai }\end{array}$ & Predikat \\
\hline 1. & $\begin{array}{l}\text { Berdoa sebelum dan } \\
\text { sesudah melakukan } \\
\text { kegiatan pembelajaran }\end{array}$ & 79,84 & 3,19 & B \\
\hline 2. & $\begin{array}{l}\text { Mengucapkan salam } \\
\text { sebelum dan sesudah } \\
\text { kegiatan pembelajaran }\end{array}$ & 75,81 & 3,03 & B \\
\hline 3. & $\begin{array}{c}\text { Mengungkapkan } \\
\text { kekaguman secara lisan } \\
\text { atas kebesaran Tuhan }\end{array}$ & 62,90 & 2,52 & B \\
\hline & Rata-Rata & 72,85 & 2,91 & B \\
\hline
\end{tabular}

Berdasarkan rata-rata penilaian aspek spiritual di atas diperoleh informasi bahwa hasil belajar kompetensi sikap spiritual siswa sudah mencapai batas ketuntasan. Hal ini terlihat dari rata-rata hasil belajar kompetensi sikap spiritual pada siklus I sebesar 2,91 dengan kategori Baik (B).

Selain hasil belajar kompetensi sikap spiritual, peneliti juga mengamati hasil belajar kompetensi sikap sosial siswa dengan memperhatikan dua jenis sikap, yaitu rasa ingin tahu dan disiplin. Kedua jenis sikap ini merupakan tolak ukur untuk melihat seberapa besar hasil belajar siswa pada kompetensi sikap sosial. Penilaian terhadap sikap sosial siswa juga dilakukan dalam setiap pertemuan melalui observasi oleh peneliti secara langsung.

Secara singkat hasil penilaian sikap sosial yang diperoleh siswa dapat dilihat pada tabel berikut: 
Tabel 5. Perolehan Penilaian Sikap Sosial pada Siklus I

\begin{tabular}{|c|c|c|c|c|}
\hline \multirow[b]{2}{*}{ No. } & \multirow[b]{2}{*}{ Sikap } & \multirow{2}{*}{$\begin{array}{c}\text { Perolehan } \\
\text { Ketercapaian } \\
\text { (Rerata Kelas) } \\
\text { dalam } \%\end{array}$} & \multicolumn{2}{|c|}{ Penilaian } \\
\hline & & & $\begin{array}{l}\text { Konversi } \\
\text { Nilai }\end{array}$ & Predikat \\
\hline 1. & Rasa Ingin Tahu & 68,82 & 2,75 & B \\
\hline 2. & Disiplin & 69,76 & 2,79 & B \\
\hline & Rata-Rata & 69,29 & 2,77 & B \\
\hline
\end{tabular}

Berdasarkan rata-rata penilaian aspek sosial di atas diperoleh informasi bahwa hasil belajar kompetensi sikap sosial siswa sudah mencapai batas ketuntasan. Hal ini terlihat dari rata-rata hasil belajar kompetensi sikap sosial pada siklus I sebesar 2,77 dengan kategori Baik (B).

3) Deskripsi Hasil Belajar Matematika (Kompetensi Pengetahuan) pada Siklus I

Pada akhir siklus I dilaksanakan tes akhir siklus I untuk memperoleh hasil belajar matematika siswa setelah mengaplikasikan strategi kognitif dalam belajar matematika.

Jika skor nilai hasil tes siklus I siswa dikelompokkan ke dalam kategori tuntas dan tidak tuntas hasil belajarnya maka diperoleh tabel distribusi frekuensi dan persentase sebagai berikut:

Tabel 6. Distribusi Frekuensi Ketuntasan Hasil Belajar Matematika Siswa Pada Tes Siklus I

\begin{tabular}{llcc}
\hline \multicolumn{1}{c}{ Skor } & Kategori & Frekuensi & Persentase \\
\hline $0<$ Skor $\leq 2,66$ & Tidak Tuntas & 10 & $32,26 \%$ \\
$2,66<$ Skor $\leq 4,00$ & Tuntas & 21 & $67,74 \%$ \\
Jumlah & & 31 & $100 \%$ \\
\hline
\end{tabular}

Tabel diatas Menunjukkan bahwa persentase ketuntasan hasil belajar matematika siswa pada tes siklus I sebesar $32,26 \%$ atau 10 dari 31 siswa termasuk dalam kategori tidak tuntas belajar dan $67,74 \%$ atau 21 dari 31 siswa termasuk dalam kategori tuntas belajar.

4) Analisis Hasil Refleksi tentang Respon Siswa

Pada akhir siklus I dibuat pertanyaan-pertanyaan refleksi. Hasil analisis terhadap refleksi tersebut dapat dilihat pada tabel berikut: 
Tabel 7. Rekapitulasi Persentase Data Hasil Angket Respon Siswa Pada Siklus I

\begin{tabular}{|c|c|c|c|}
\hline \multirow{2}{*}{ No. } & \multirow{2}{*}{ Item } & \multicolumn{2}{|c|}{ Jumlah Siswa } \\
\hline & & Positif & Negatif \\
\hline 1. & $\begin{array}{l}\text { Pendapat siswa terhadap } \\
\text { matematika }\end{array}$ & $74,19 \%$ & $25,81 \%$ \\
\hline 2. & $\begin{array}{lrr}\text { Tanggapan siswa } & \text { terhadap } \\
\text { pengaplikasian } & \text { strategi } & \text { kognitif } \\
\text { dalam belajar matematika } & \end{array}$ & $100 \%$ & $0 \%$ \\
\hline 3. & $\begin{array}{l}\text { Hambatan yang ditemui siswa saat } \\
\text { mengaplikasikan strategi kognitif } \\
\text { dalam belajar matematika }\end{array}$ & $35,48 \%$ & $64,52 \%$ \\
\hline 4 & $\begin{array}{l}\text { Pendapat siswa tentang bagaimana } \\
\text { seharusnya cara guru memberikan } \\
\text { arahan/bimbingan mengenai } \\
\text { pengaplikasian strategi kognitif }\end{array}$ & $58,06 \%$ & $41,94 \%$ \\
\hline Rata- & Rata & $66,93 \%$ & $33,07 \%$ \\
\hline
\end{tabular}

Berdasarkan tabel 7, dapat disimpulkan bahwa dari empat item yang direspon, terdapat $66,93 \%$ siswa yang memberikan respon yang positif dan $33,07 \%$ yang memberikan respon yang negatif terhadap pengaplikasian strategi kognitif dalam belajar matematika.

d. Tahap Refleksi

Berdasarkan rangkaian kegiatan berupa perencanaan tindakan, pelaksanaan tindakan, dan observasi yang telah dilakukan maka yang menjadi perhatian utama pada tahap refleksi, yaitu hasil belajar matematika kompetensi pengetahuan siswa. Dari tabel 4.13 dan tabel 4.15 menunjukkan bahwa tes hasil belajar sudah mengalami peningkatan dari tes awal. Namun, belum optimal karena belum mencapai Kriteria Ketuntasan Minimal mata pelajaran matematika yakni $75 \%$ siswa memperoleh nilai minimal 2,66. Oleh karena itu, penelitian dilanjutkan ke siklus II.

Mencermati permasalahan yang timbul pada siklus I, peneliti bersama observer berdiskusi dan merencanakan langkah-langkah perbaikan yang akan diterapkan pada siklus II untuk memperbaiki kelemahan dan mempertahankan keberhasilan yang telah dicapai pada siklus I, yaitu:

1) Meningkatkan pemberian apersepsi dan memotivasi siswa untuk aktif dalam pembelajaran sehingga tujuan pembelajaran dapat tercapai. 
2) Meningkatkan dan menyempurnakan pemberian contoh-contoh tentang pengaplikasian strategi kognitif dengan baik dan benar sehingga lebih memudahkan siswa untuk memahami materi pelajaran.

\section{Siklus II}

a. Tahap Perencanaan (Planning)

Pada siklus II, proses pembelajaran dilakukan sebanyak empat kali pertemuan. Setelah memperhatikan hasil refleksi pada siklus I, maka pada siklus II peneliti melakukan perencanaan kembali sebelum melakukan tindakan pada kegiatan pembelajaran berikutnya, seperti merancang kembali instrumen penelitian yang akan digunakan pada siklus II. Semua instrumen yang digunakan pada siklus II ini merupakan instrumen lanjutan dari siklus I berupa Rencana Pelaksanaan Pembelajaran (RPP), Lembar Kerja Siswa (LKS), lembar observasi aktivitas siswa, lembar observasi aktivitas guru, dan angket respon siswa.

b. Tahap Pelaksanaan Tindakan (Acting)

Seperti halnya pada siklus I, semua kegiatan pembelajaran pada siklus II diimplementasikan dalam pembelajaran berdasarkan Rencana Pelaksanaan Pembelajaran (RPP). Selama praktik pembelajaran berlangsung, peneliti mengarahkan dan/atau membimbing siswa agar tetap mengaplikasikan strategi kognitif dalam belajar matematika. Selain itu, peneliti juga tetap mendampingi dan mengawasi siswa sehingga jika ada kesalahan dalam proses belajar guru dapat memberi arahan untuk menunjang kesempurnaan jalannya proses belajar mengajar.

c. Tahap Observasi (Observating)

1) Analisis Hasil Observasi Siklus II

Selama pembelajaran berlangsung observer melakukan pengamatan dengan menggunakan instrumen yang sudah disiapkan. Adapun observasi yang dilakukan meliputi aktivitas siswa, aktivitas guru, dan hasil belajar kompetensi sikap (spiritual dan sosial) siswa. Berdasarkan lembar observasi aktivitas siswa dengan mengaplikasikan strategi kognitif dalam belajar matematika diperoleh hasil sebagai berikut: 
Tabel 8. Hasil Observasi Aktivitas Siswa pada Siklus II

\begin{tabular}{ccc}
\hline No. & $\begin{array}{c}\text { Indikator Observasi Aktivitas } \\
\text { Siswa }\end{array}$ & $\begin{array}{c}\text { Perolehan (Rerata) } \\
\text { Kelas }\end{array}$ \\
\hline 1. & Strategi Mengulang & 38 \\
2. & Strategi Elaborasi & 65 \\
3. & Strategi Organisasi & 35 \\
\hline & Jumlah & 138 \\
\hline & Rata-Rata & 46
\end{tabular}

Berdasarkan tabel 8 diperoleh informasi bahwa rata-rata aktivitas siswa mengalami peningkatan sebesar 3 poin dari perolehan rata-rata aktivitas siswa pada siklus I.

2) Analisis penilaian sikap spritual dan sosial siklus II

Selain observasi yang dilakukan oleh observer terhadap aktivitas siswa, peneliti juga melakukan observasi terhadap hasil belajar kompetensi sikap (spiritual dan sosial) siswa. Secara singkat hasil penilaian sikap spiritual yang diperoleh siswa dideskripsikan sebagai berikut.

Tabel 9. Perolehan Penilaian Sikap Spiritual Pada Siklus II

\begin{tabular}{|c|c|c|c|c|}
\hline \multirow[b]{2}{*}{ No. } & \multirow[b]{2}{*}{ Indikator } & \multirow{2}{*}{$\begin{array}{c}\text { Perolehan } \\
\text { Ketercapaian } \\
\text { (Rerata Kelas) } \\
\text { dalam \% }\end{array}$} & \multicolumn{2}{|c|}{ Penilaian } \\
\hline & & & $\begin{array}{c}\text { Konversi } \\
\text { Nilai }\end{array}$ & Predikat \\
\hline 1. & $\begin{array}{l}\text { Berdoa sebelum dan } \\
\text { sesudah } \\
\text { kegiatan }\end{array}$ & 96,77 & 3,87 & SB \\
\hline 2. & $\begin{array}{l}\text { Mengucapkan salam } \\
\text { sebelum dan sesudah } \\
\text { kegiatan pembelajaran }\end{array}$ & 79,84 & 3,19 & B \\
\hline 3. & $\begin{array}{l}\text { Mengungkapkan } \\
\text { kekaguman secara lisan } \\
\text { atas kebesaran Tuhan }\end{array}$ & 79,84 & 3,19 & B \\
\hline & Rata-Rata & 85,48 & 3,42 & SB \\
\hline
\end{tabular}

Berdasarkan rata-rata penilaian aspek spiritual di atas diperoleh informasi bahwa hasil belajar kompetensi sikap spiritual siswa mengalami peningkatan sebesar 0,51 dengan predikat Sangat Baik (SB).

60 | Volume 5, Nomor 1, Juni 2017 
Tabel 10. Perolehan Penilaian Sikap Sosial pada Siklus II

\begin{tabular}{|c|c|c|c|c|}
\hline \multirow[b]{2}{*}{ No. } & \multirow[b]{2}{*}{ Sikap } & \multirow{2}{*}{$\begin{array}{c}\text { Perolehan } \\
\text { Ketercapaian } \\
\text { (Rerata Kelas) } \\
\text { dalam \% }\end{array}$} & \multicolumn{2}{|c|}{ Penilaian } \\
\hline & & & $\begin{array}{c}\text { Konversi } \\
\text { Nilai }\end{array}$ & Predikat \\
\hline 1. & Rasa Ingin Tahu & 76,08 & 3,04 & B \\
\hline 2. & Disiplin & 78,63 & 3,15 & B \\
\hline & Rata-Rata & 77,35 & 3,09 & B \\
\hline
\end{tabular}

Berdasarkan rata-rata penilaian aspek sosial di atas diperoleh informasi bahwa hasil belajar kompetensi sikap sosial siswa mengalami peningkatan sebesar 0,32 tetapi secara predikat tetap berada pada kategori Baik (B).

3) Deskripsi Hasil Belajar Matematika (Kompetensi Pengetahuan) Siklus II

Setelah siswa mengaplikasikan strategi kognitif dalam belajar matematika pada siklus II maka penulis memberikan tes akhir siklus II untuk melihat apakah ada perubahan terhadap hasil belajar matematika.

Tabel 11. Distribusi Frekuensi dan Persentase Skor Hasil Belajar Matematika Siswa pada Siklus II

\begin{tabular}{lllcc}
\hline No. & Rentang Nilai & Predikat & Frekuensi & Persentase \\
\hline 1. & $0<$ Skor $\leq 1,00$ & $\mathrm{D}$ & - & - \\
2. & $1,00<$ Skor $\leq 1,33$ & $\mathrm{D}^{+}$ & - & - \\
3. & $1,33<$ Skor $\leq 1,66$ & $\mathrm{C}^{-}$ & - & - \\
4. & $1,66<$ Skor $\leq 2,00$ & $\mathrm{C}$ & - & - \\
5. & $2,00<$ Skor $\leq 2,33$ & $\mathrm{C}^{+}$ & - & - \\
6. & $2,33<$ Skor $\leq 2,66$ & $\mathrm{~B}^{-}$ & 3 & $9,68 \%$ \\
7. & $2,66<$ Skor $\leq 3,00$ & $\mathrm{~B}$ & 8 & $25,81 \%$ \\
8. & $3,00<$ Skor $\leq 3,33$ & $\mathrm{~B}^{+}$ & 16 & $51,61 \%$ \\
9. & $3,33<$ Skor $\leq 3,66$ & $\mathrm{~A}^{-}$ & 4 & $12,90 \%$ \\
10. & $3,66<$ Skor $\leq 4,00$ & $\mathrm{~A}$ & - & - \\
\hline \multicolumn{5}{l}{ Jumlah } \\
\hline
\end{tabular}

Berdasarkan tabel 11 di atas dapat diketahui bahwa dari 31 siswa yang ikut tes siklus II diperoleh hasil bahwa sebanyak 3 siswa (9,68 \%) yang memperoleh nilai dengan predikat $B-, 8$ siswa $(25,81 \%)$ yang memperoleh nilai 
dengan predikat $B, 16$ siswa $(51,61 \%)$ yang memperoleh nilai dengan predikat $\mathrm{B}^{+}$, dan 4 siswa $(12,90 \%)$ yang memperoleh nilai dengan predikat $\mathrm{A}^{-}$.

Selanjutnya, jika skor nilai hasil tes siklus II siswa dikelompokkan ke dalam kategori tuntas dan tidak tuntas hasil belajarnya maka diperoleh tabel distribusi frekuensi dan persentase sebagai berikut:

Tabel 12. Distribusi Frekuensi Ketuntasan Hasil Belajar Matematika Siswa Pada Tes Siklus II

\begin{tabular}{llcc}
\hline \multicolumn{1}{c}{ Skor } & \multicolumn{1}{c}{ Kategori } & Frekuensi & Persentase \\
\hline $0<$ Skor $\leq 2,66$ & Tidak Tuntas & 3 & $9,68 \%$ \\
$2,66<$ Skor $\leq 4,00$ & Tuntas & 28 & $90,32 \%$ \\
\hline Jumlah & & 31 & $100 \%$ \\
\hline
\end{tabular}

Tabel 12 menunjukkan bahwa persentase ketuntasan hasil belajar matematika siswa pada tes siklus II sebesar 9,68 \% atau 3 dari 31 siswa termasuk dalam kategori tidak tuntas belajar dan $90,32 \%$ atau 28 dari 31 siswa termasuk dalam kategori tuntas belajar.

4) Analisis Hasil Refleksi tentang Respon siswa

Untuk mengetahui tanggapan siswa terhadap pengaplikasian strategi kognitif pada siklus II, peneliti juga memberikan sejumlah pertanyaan tertulis kepada siswa yang tertuang dalam angket (refleksi) tanggapan siswa. Hasil analisis terhadap refleksi tersebut dapat dilihat pada tabel berikut:

Tabel 13. Rekapitulasi Persentase Data Hasil Angket Respon Siswa Pada Siklus II

\begin{tabular}{|c|c|c|c|}
\hline \multirow{2}{*}{ No. } & \multirow{2}{*}{ Item } & \multicolumn{2}{|c|}{ Jumlah Siswa } \\
\hline & & Positif & Negatif \\
\hline 1. & $\begin{array}{l}\text { Pendapat } \\
\text { matematika }\end{array}$ & $87,10 \%$ & $12,90 \%$ \\
\hline 2. & $\begin{array}{lrr}\text { Tanggapan siswa } & \text { terhadap } \\
\text { pengaplikasian } & \text { strategi } & \text { kognitif } \\
\text { dalam belajar matematika } & \end{array}$ & $100 \%$ & $0 \%$ \\
\hline 3. & $\begin{array}{l}\text { Hambatan yang ditemui siswa saat } \\
\text { mengaplikasikan strategi kognitif } \\
\text { dalam belajar matematika }\end{array}$ & $90,32 \%$ & $9,68 \%$ \\
\hline 4. & Pendapat siswa tentang bagaimana & $83,87 \%$ & $16,13 \%$ \\
\hline
\end{tabular}

62 | Volume 5, Nomor 1, Juni 2017 


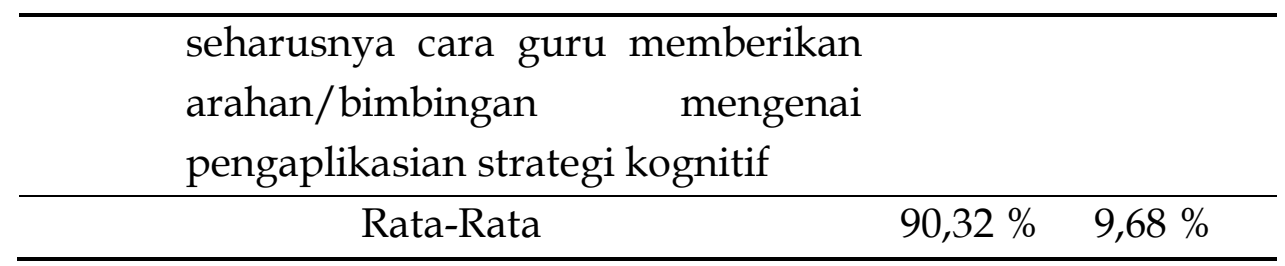

Berdasarkan tabel 13 diperoleh informasi bahwa respon positif siswa terhadap pengaplikasian strategi kognitif mengalami peningkatan sebesar $23,39 \%$.

\section{d. Refleksi}

Pelaksanaan tindakan pada siklus II pada dasarnya sama dengan pelaksanaan tindakan pada siklus I. Namun ada beberapa hal yang direvisi untuk lebih mengaktifkan siswa dalam mengikuti pelajaran.

Secara umum dapat dikatakan bahwa kegiatan pada siklus II mengalami peningkatan dari siklus I, baik dilihat dari hasil belajar matematika siswa, aktivitas siswa maupun respon siswa terhadap pengaplikasian strategi kognitif. Oleh karena itu, peneliti mengakhiri pelaksanaan tindakan pada penelitian ini sampai pada siklus II.

Penelitian ini dimulai dengan melakukan kegiatan observasi awal dan kegiatan wawancara dengan guru bidang studi Matematika wajib kelas $\mathrm{X}$ Matematika dan Ilmu Alam (MIA) 5 SMA Negeri 2 Palopo Kelurahan Rampoang Kecamatan Bara Kota Palopo. Dari hasil kegiatan tersebut diperoleh fakta bahwa kemampuan siswa dalam memahami materi pelajaran matematika masih rendah. Untuk membuktikan hal tersebut, peneliti mengikuti dan mengamati proses pembelajaran selama beberapa pertemuan dimana guru yang mengajar pada kelas tersebut adalah guru bidang studi matematika wajib. Selanjutnya, untuk memperkuat fakta tersebut, peneliti memberikan tes awal kepada siswa kelas X Matematika dan Ilmu Alam (MIA) 5 SMA Negeri 2 Palopo sebagai acuan untuk mengetahui hasil belajar matematika siswa sebelum pelaksanaan tindakan.

Berdasarkan hasil penelitian, diperoleh bahwa sebelum diaplikasikannya strategi kognitif dalam belajar matematika, skor tertinggi siswa berada pada angka 2,60 dan skor terendah siswa pada angka 0,80 dengan skor rata-rata 1,61 predikat C-

Rendahnya kemampuan siswa dalam memahami materi pelajaran matematika, antara lain disebabkan karena siswa belum mengetahui bagaimana seharusnya belajar itu. Berdasarkan hal tersebut, maka penulis 
merasa perlu melakukan penelitian tindakan kelas dengan mengaplikasikan strategi kognitif dalam belajar matematika siswa. Melalui pengaplikasian strategi kognitif, pemahaman siswa terhadap materi yang dipelajari dan kemampuan siswa untuk menjadi pembelajar yang mandiri semakin terasah, sehingga ketergantungan antara siswa kepada guru dalam proses pembelajaran semakin berkurang. Hal ini sesuai dengan implementasi kurikulum 2013 yang menuntut agar siswa mampu menemukan sendiri konsep dari masalah yang dipelajari.

Pada siklus I dilaksanakan tes akhir siklus I yang berbentuk ulangan harian setelah penyajian dua sub pokok bahasan yaitu menemukan konsep logaritma dan sifat-sifat logaritma. Setelah mengaplikasikan strategi kognitif dalam belajar matematika diperoleh skor rata-rata hasil belajar matematika kompetensi pengetahuan pada siklus I adalah 2,6142 dengan predikat B-. Hal ini menunjukkan bahwa pembelajaran pada siklus I belum optimal karena persentase ketuntasan klasikal hanya 7,26 \% lebih rendah dari Kriteria Ketuntasan Klasikal, yaitu $75 \%$.

Berdasarkan hasil refleksi, belum tercapainya Kriteria Ketuntasan Minimal diduga disebabkan karena beberapa hal antara lain siswa masing asing dengan pembelajaran yang mengaplikasikan strategi kognitif dalam belajar matematika, meskipun sudah diperkenalkan sebelumnya. Secara umum, belajar dengan mengaplikasikan strategi kognitif merupakan hal yang baru bagi siswa. Selain itu, siswa belum berani mengajukan pertanyaan, mengeluarkan pendapat atau menanggapi pertanyaan dari teman/guru karena mereka takut salah.

Selanjutnya, sebelum melaksanakan siklus II, peneliti melakukan upaya perbaikan agar kendala-kendala yang terjadi pada siklus I tidak timbul kembali pada siklus II. Adapun langkah-langkah yang dimaksud meliputi menjelaskan kembali kepada siswa tentang cara untuk mengaplikasikan strategi kognitif dalam belajar, mengarahkan dan/atau membimbing siswa untuk tetap mengaplikasikan strategi kognitif dalam belajar serta mengarahkan siswa yang cepat belajar untuk menjadi tutor sebaya bagi siswa lain yang lambat belajar dalam mengatasi kesulitan dalam memahami pelajaran. Setelah upaya-upaya perbaikan ini diterapkan, peneliti melaksanakan siklus II.

Berdasarkan tabel 4.22, dapat disimpulkan bahwa setelah mengaplikasikan strategi kognitif dalam belajar matematika, hasil belajar siswa mengalami peningkatan. Hal ini terlihat dari skor rata-rata dari 2,6142 
dengan predikat B- pada siklus I dan terus meningkat menjadi 3,0697 dengan predikat $\mathrm{B}^{+}$pada siklus II. Begitu pula dengan persentase ketuntasan klasikal hasil belajar matematika juga mengalami peningkatan dari $67,74 \%$ menjadi $90,32 \%$.

Sementara itu, hasil belajar kompetensi sikap (spiritual dan sosial) siswa juga mengalami peningkatan dari siklus I ke siklus II. Hal ini dapat dilihat dari skor rata-rata hasil belajar kompetensi sikap spiritual siswa sebesar 2,91 dengan predikat B (Baik) meningkat menjadi 3,42 dengan predikat SB (Sangat Baik). Sedangkan skor rata-rata hasil belajar kompetensi sikap sosial siswa pada siklus I sebesar 2,77 dengan predikat B (Baik) dan pada siklus II meningkat menjadi 3,09 meskipun secara klasifikasi sikap tetap berada pada predikat B (Baik).

Selain hasil belajar matematika, aktivitas siswa juga mengalami peningkatan dari siklus I ke siklus II. Hal ini dapat dilihat dari skor rata-rata aktivitas siswa pada siklus I sebesar 43 dan terus meningkat menjadi 46 pada siklus II. Strategi kognitif yang diaplikasikan pada siklus II juga lebih kompleks, yaitu strategi elaborasi dan strategi organisasi tetapi bukan berarti strategi mengulang tidak diaplikasikan. Sebaliknya, pada siklus I strategi yang mendominasi proses belajar siswa adalah strategi mengulang. Hal ini disebabkan karena strategi tersebut merupakan strategi yang paling mudah untuk diaplikasikan dibanding strategi yang lain.

Berdasarkan hasil analisis terhadap refleksi atau tanggapan siswa mengenai pengaplikasian strategi kognitif dalam belajar matematika dapat disimpulkan bahwa secara umum, respon positif yang diberikan oleh siswa dari siklus I ke siklus II mengalami peningkatan dari 66,93 \% menjadi 90,32 \%. Ini menunjukkan bahwa strategi kognitif layak dan efektif digunakan untuk meningkatkan kemampuan siswa dalam memahami materi pembelajaran logaritma.

\section{SIMPULAN}

Hasil observasi aktivitas siswa kelas X Matematika dan Ilmu Alam (MIA) SMA Negeri 2 Palopo pada siklus I sebesar 43 dan terus meningkat pada siklus II menjadi 46. Hasil refleksi tentang respon positif siswa mengenai pengaplikasian strategi kognitif dalam belajar matematika pada siklus I sebesar $66,93 \%$ dan pada siklus II meningkat menjadi 90,32 \%. Rata-rata hasil belajar matematika kompetensi pengetahuan siswa kelas $\mathrm{X}$ Matematika dan Ilmu Alam (MIA) 5 SMA Negeri 2 Palopo pada siklus I adalah 2,6142 dari skor 
ideal 4 dengan predikat B- dan nilai rata-rata siklus II adalah 3,0697 dari skor ideal 4 dengan predikat $\mathrm{B}^{+}$.

Rata-rata hasil belajar kompetensi sikap spiritual siswa kelas $\mathrm{X}$ Matematika dan Ilmu Alam (MIA) 5 SMA Negeri 2 Palopo pada siklus I berada pada predikat B (Baik) dengan perolehan ketercapaian rata-rata 72,85 $\%$ dengan konversi nilai 2,91 sedangkan pada siklus II meningkat menjadi 85,48 \% dengan konversi nilai 3,42 atau secara klasifikasi sikap berada pada predikat SB (Sangat Baik). Rata-rata hasil belajar kompetensi sikap sosial siswa kelas X Matematika dan Ilmu Alam (MIA) 5 SMA Negeri 2 Palopo pada siklus I berada pada predikat B (Baik) dengan perolehan ketercapaian rata-rata 69,29 $\%$ dengan konversi nilai 2,77 sedangkan pada siklus II meningkat menjadi 77,35 \% dengan konversi nilai 3,09 meskipun secara klasifikasi sikap tetap berada pada predikat B (Baik). Pengaplikasian strategi kognitif dalam pembelajaran dapat meningkatkan kemampuan siswa dalam memahami materi pembelajaran logaritma siswa kelas X Matematika dan Ilmu Alam (MIA) 5 SMA Negeri 2 Palopo.

\section{DAFTAR PUSTAKA}

Arikunto, S. (2011). Penelitian tindakan kelas. Cet. X; Jakarta: Bumi Aksara.

Darmadi, H. (2011). Metode penelitian pendidikan. Bandung: Alfabeta.

Departemen Agama. (2012). Al Qur'an dan terjemahannya. Bandung: Al-Mizan Publishing House.

Djamarah, B. S., dan Zain A. (2010). Strategi belajar mengajar. Cet. IV; Jakarta: Rineka Cipta.

Kementrian Pendidikan dan Kebudayaan. (2013). Buku guru matematika. Ed. Revisi; Jakarta: Politeknik Negeri Media Kreatif.

Kuswana, S. W. (2012). Taksonomi kognitif. Bandung: Remaja Rosdakarya.

Sabri, A. (2005). Strategi belajar mengajar dan micro teaching. Jakarta: Quantum Teaching.

Suprihatiningrum, J. (2013). Strategi pembelajaran: teori dan aplikasi. Yogyakarta: Ar-Ruzz Media.

Trianto. (2011). Model-model pembelajaran inovatif berorientasi konstruktivistik:

66 | Volume 5, Nomor 1, Juni 2017 
Konsep, landasan teoritis-praktis dan implementasinya. Jakarta: Prestasi Pustaka Publisher.

Giyato. (2013). "Implementasi kurikulum 2013," Kabar Makassar Online. 28 September 2013. http://m.suaramerdeka.com/index.php/read/cetak/2013/12/28/2476 38 (19 Februari 2014).

Ilham. (2014). Penerapan strategi elaborasi dalam meningkatkan hasil belajar matematika siswa kelas $\mathrm{VIII}_{\mathrm{A}}$ MTS Al-Jihad Buangin Kecamatan Sabbang Kabupaten Luwu Utara. Skripsi. Palopo: STAIN Palopo.

Wilantika. (2014). Peningkatan hasil belajar matematika melalui penerapan peta konsep terhadap siswa kelas VII.3 SMP Negeri 1 Walenrang. Skripsi. Palopo: STAIN Palopo. 